\title{
THE DEVELOPMENT OF OVERHEAD PASS LEARNING MODELS IN VOLEYBALL
}

\author{
Destriana $^{1}$, Muslimin ${ }^{2}$, Destriani \\ Universitas Sriwijaya $^{1,3}$, Universitas Bina Darma ${ }^{2}$ \\ destriana@fkip.unsri.ac.id, muslimin@binadarma.ac.id, destriani@fkip.unsri.ac.id
}

\begin{abstract}
This study aims to develop a learning model of overhead pass volleyball for class VIII junior high school students. This study uses research and development research methods with the ADDIE model (Analysis, Design, Development or Production, Implementation or Delivery and Evaluations). The subjects in this study were students of Junior High School No 1 Palembang Class VIII in 2018/2019. Qualitative and quantitative data analysis techniques. This research was conducted up to the development stage, namely large-scale trials. The validation of this model of overhead pass was carried out by experts in phycical education, volleyball game experts, and linguists. The results of the model validation (Design stage) of this top learning model obtained a percentage of $87.5 \%$ of Physical education experts, $90 \%$ of volleyball game experts, and $87.5 \%$ of linguists from the results of expert validation show that the learning model is the top volleyball game Valid or worth using. The development stage consists of one-on-one evaluations, small group trials, and large group trials. The results of the large group trial were obtained using the instrument of the upper pass motion assessment process, the percentage was $12.5 \%$ or 3 students were very good, $87.5 \%$ of students got good grades or as many as 21 students. Based on large group trials, the product in the form of a learning model for volleyball can be used in the volleyball learning process. For further research, it can test the effectiveness of the development of the passing over model so that it can be seen the effect of this model when used in volleyball learning.
\end{abstract}

Keywords: Learning Model, Overhead Pass, Volleyball Game

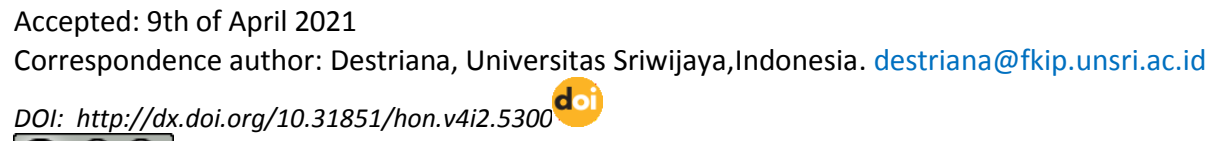

Halaman Olahraga Nusantara Journal licensed under a Creative Commons Attribution-ShareAlike 4.0 International License.

\section{INTRODUCTION}

Learning is a process of regulating, organizing the environment around students so that it can grow and encourage students to carry out the learning process, learning is said to be a process of providing guidance and assistance to students in carrying out the learning process (Pane \& Darwis Dasopang, 2017). The quality of physical education learning and is determined by various factors, 
one of which is the ability of teachers to teach and assess students, without having these two abilities, physical education teachers will find it difficult to realize the effectiveness and efficiency of teaching which impacts on the difficulty of achieving maximum physical education learning goals. Therefore, physical education teachers must understand the mastery of this knowledge (Tomoliyus, T., Margono, M., \& Sujarwo, S, 2013). One of the materials in physical education learning is volleyball.

Volleyball game is an educational sport, recreation and achievement sport, as an educational sport, volleyball game is taught through the learning process of physical education, sports and health. Facts in the field show that students experience difficulty and disinterest in participating in the volleyball learning process. So that the game can provoke student participation, there needs to be a development and modification of the volleyball game. On the other hand, modifications must also be made in relation to the facilities and infrastructure. Thus, the challenge of developing volleyball in students at least boils down to the development of a volleyball learning model. Volleyball is characterized as a ball game that requires biomechanical demands upon the musculoskeletal system as well as great deal of neuromuscular coordination, speed, agility, and power. Passing, setting, spiking, blocking and serving the ball are fundamental movements in a volleyball game, which requires implementation of various vertical or horizontal jumps, and speed actions. It has been suggested that volleyball players competing in better performing teams, have higher vertical jump values (Ikeda, Sasaki, \& Hamano, 2018). Teknik-teknik dalam permainan bola voli adalah seperti smash, blok, pasing atas, pasing bawah dan servis atas dan servis bawah.

Previous research on the development of the upper pass model, namely (Rohendi, 2020) where the development of a learning model for playing volleyball based on the results of his research on the game of volleyball increased using this model, then research from (Destriana, 2019) it can be improved through double-control upper pairing exercises in pairs, then other research on volleyball, namely (Marsiyem, Destriana, \& Pratama, 2018), regarding the 
development of a lower pass learning model which is able to improve lower pass learning outcomes, beside that (Pratiwi \& Anggara, 2021) in the underpass model of volleyball for beginner athletes, students of UNISKA MAB Banjarmasin, has received a positive response and can be applied to beginner athletes of UNISKA MAB Banjarmasin students, next research (Daryono \& Almy, 2021) on self-check style affects the results of volleyball skills, based on the results of research that has been done there is an increase in volleyball playing skills through shelf check style training, an increase in volleyball service skills, an increase in passing skills and an increase in volleyball smash skills. Previous research on upper passing has not seen any research on the development of overhead pass learning for junior high school students, so this study will develop a overhead passing learning model of volleyball in Class VIII students at Junior High School No 1 Palembang. The development of the upper passing learning model was carried out because seeing the problems in top-fitting learning that occurred in the field, it was seen that students did not master the overhead pass technique, looked lazy and were not serious in participating in overhead pass learning, based on this field analysis there was a need for solutions in addressing them.

The learning model for volleyball playing which is developed will be more in line with the characteristics of junior high school students, because the concept of the pasing learning model for playing volleyball is designed to assist students in developing upper passing skills. The pasing learning model for this volleyball game emphasizes a fun learning experience and is in accordance with the characteristics of students. The research aims to develop a learning model for volleyball playing in class VIII students, with this research it is hoped that it can be used by PJOK teachers as an additional learning model that can be used in volleyball games, especially the upper pass model.

\section{METHOD}

The research method used in this research is research and development. Development steps use the ADDIE model according to Branch (2009: 2), namely ADDIE stands for Analysis, Design, Development or Production, Implementation 
or Delivery and Evaluations. This research is at the Development stage. This research uses quantitative and qualitative data analysis techniques. Quantitative data is shown in managing validation result questionnaires and observations and qualitative data based on input and suggestions from expert validation on product design. By using a questionnaire instrument as a data collector of validation results and observations to see the validity of the fitting model for volleyball. This research was conducted in the march-may 2019 year class VIII as respondents to the trial totaling 24 students. This study uses a purposive sampling model because it is in accordance with the research objectives.

\section{RESULT AND DISCUSSION}

\section{RESULT}

The initial stage of this research is analysis. In this study, the results of the analysis obtained the following results:

Table 1. Field Analysis Table

No.

What is provided in the learning The process of passing over class VIII in volleyball for students who take volleyball game material?

2 Is the passing learning material for class VIII delivered in a variety of less varied ways during the volleyball game material?

3 Are the facilities and infrastructure available for overhead pass class VIII in volleyball?
Findings

The teacher provides learning material for passing over during volleyball learning

Learning is done in a manoton and

It is quite good that there are facilities and infrastructure used by the volleyball field and the tools used to support learning of overhead pass 
No.

Question Points

4 How is the application of the passing learning model for class VIII in volleyball games commonly done?

5 How is the student's motivation when the material passes over class VIII in volleyball?

6 Are there any efforts made by the teacher in dealing with problems that arise in learning overhead pass volleyball?

\section{Findings}

Good enough but less varied in implementation.

Students seem not very motivated in participating in learning because the material is monotonous.

So far, the teacher only provides a limited learning model, students are only given a few learning models in the material, the teacher emphasizes more on game model exercises, the teacher has not provided interesting learning variations that can improve the quality of the top-level results.

7 Is it necessary to develop overhead In general, teachers need a variety pass learning model for class VIII of learning models that can be used in volleyball? in learning that can provide comfort and safety and maximum results in the process and each material..

The next stage is the design stage where the upper pass developed consists of 12 overhead pass models, the models developed are as follows:

a. Overhead pass learning model without the ball in place 
b. The learning model of overhead pass forward 3 steps to touch the cone without the ball

c. Learning model of overhead pass 3 steps backwards touching the cone

d. Learning model overhead pass left side 3 steps touching the cone

e. Learning model overhead pass right side 3 steps touching the cone

f. Overhead pass passive learning model with the help of friends

g. Overhead pass learning model in place using a ball

h. Overhead pass learning model moves forward 3 steps to touch the cone with the help of using a ball

i. Overhead pass learning model moves backward 3 steps to touch the cone with the ball with the help of a friend

j. Overhead pass e upper pass learning model moves to the left side 3 steps to touch the cone with assistance

k. Overhead pass learning model moves to the right side 3 steps to touch the cone with assistance

1. Overhead pass learning model while walking forward

The 12 models that have been designed are then validated by 3 experts, namely Physical Education, Sports and Health (experts, volleyball game experts and linguists. The validation results were obtained as follows:

Table 2. The results of the assessment of the volleyball expert validation "development of a learning model of overhead pass volleyball games for Class VIII Junior High School"

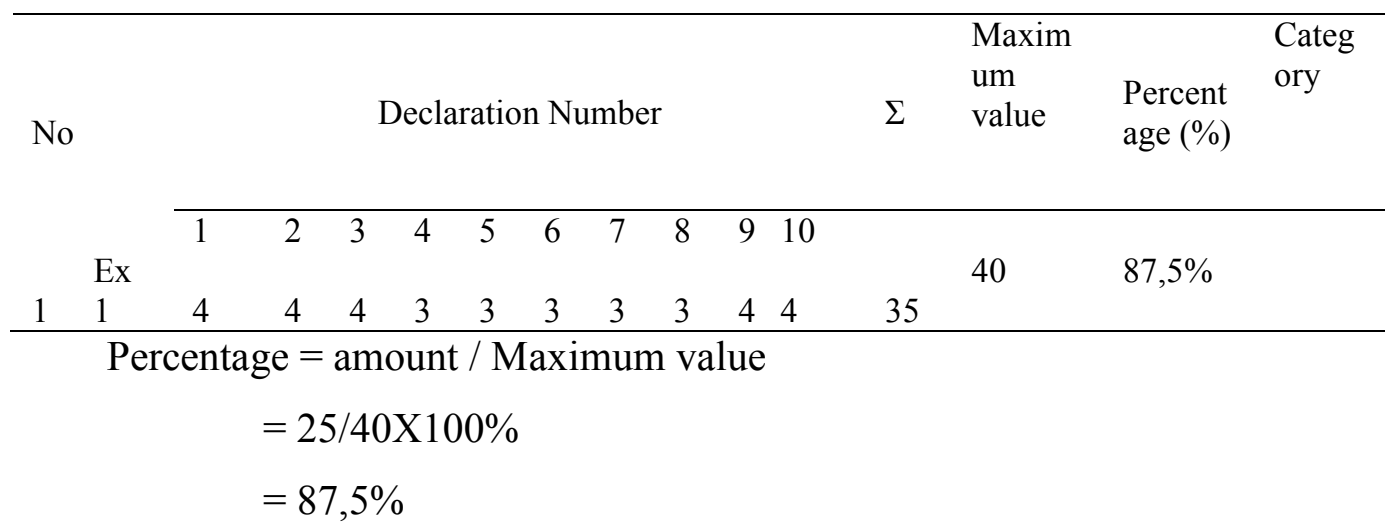


Table 3. The results of the expert validation assessment corner "the development of a learning model of overhead pass volleyball games for Class VIII Junior High

\begin{tabular}{|c|c|c|c|c|c|c|c|c|c|c|c|c|c|c|c|}
\hline \multicolumn{16}{|c|}{ Schools" } \\
\hline \multirow{2}{*}{$\begin{array}{l}\mathrm{N} \\
\mathrm{O}\end{array}$} & & \multicolumn{10}{|c|}{ Declaration Number } & $\Sigma$ & $\begin{array}{l}\text { Maxim } \\
\text { um }\end{array}$ & Percent & $\begin{array}{l}\text { Categ } \\
\text { ory }\end{array}$ \\
\hline & Ex & & & & & & & & & & & & 40 & $90 \%$ & \\
\hline 1 & 2 & 4 & 4 & 4 & 4 & 3 & 3 & 3 & 3 & 4 & 4 & 36 & & & \\
\hline
\end{tabular}

Percentage $=$ amount $/$ Maximum value

$$
\begin{aligned}
& =36 / 40 \times 100 \% \\
& =90 \%
\end{aligned}
$$

Table 4. The results of the linguist validation assessment "development of the overhead pass learning model of volleyball game for Class VIII Junior High

\begin{tabular}{|c|c|c|c|c|c|c|c|c|c|c|c|c|c|c|c|}
\hline \multirow{2}{*}{$\begin{array}{l}\mathrm{N} \\
\mathrm{o}\end{array}$} & & \multicolumn{10}{|c|}{ Declaration Number } & \multirow[t]{2}{*}{$\Sigma$} & \multirow{2}{*}{$\begin{array}{l}\text { Maxim } \\
\text { um } \\
\text { value }\end{array}$} & \multirow[t]{2}{*}{$\begin{array}{l}\text { Percent } \\
\text { age (\%) }\end{array}$} & \multirow[t]{2}{*}{$\begin{array}{l}\text { Categ } \\
\text { ory }\end{array}$} \\
\hline & & 1 & 2 & 3 & 4 & 5 & 6 & 7 & 8 & 9 & 10 & & & & \\
\hline & Ex & & & & & & & & & & & & 40 & $87,5 \%$ & \\
\hline 1 & 3 & 4 & 4 & 4 & 3 & 3 & 3 & 3 & 3 & 4 & 4 & 35 & & & \\
\hline
\end{tabular}
School"

The next stage is the development stage which consists of one-on-one trial steps, small group trials and large group trials. The one-on-one test resulted in the following results:

\begin{tabular}{|c|c|c|}
\hline No & Statement & Yes \\
\hline 1 & $\begin{array}{l}\text { The teacher / teacher can teach the development of a } \\
\text { learning model with basic overhead pass movements } \\
\text { without a ball in a volleyball game }\end{array}$ & $\sqrt{ }$ \\
\hline 2 & $\begin{array}{l}\text { The teacher / teacher can teach the development of a } \\
\text { learning model with basic overhead pass motion without }\end{array}$ & $\sqrt{ }$ \\
\hline
\end{tabular}

Table 5. Testing one on one 
the ball by moving forward and backward touching the volleyball game cone

3 The teacher can teach the development of a learning model with the basic overhead pass motion without the ball by touching the cone of the volleyball game to the left and right.

4 The teacher / teacher can teach the development of a learning model with basic overhead pass movements with a ball in a volleyball game

5 The teacher / teacher can teach the development of a learning model with basic overhead pass motion with a passive ball with the help of volleyball

6 The teacher / teacher can teach the development of a learning model with basic overhead pass motion with the ball moving back and forth touching the cone with volleyball.

7 The teacher can teach the development of a learning model with basic downward motion with the ball moving to the right and to the left touching the cone with a volleyball game.

8 The teacher / teacher can teach the development of a learning model with basic overhead pass movements with the ball running forward in a volleyball game

9 The teacher / teacher understands the rules of the overhead pass learning model developed

10 The teacher / teacher can implement the overhead pass learning model developed in accordance with existing steps

11 Ladies and gentlemen are familiar with the tools used in the overhead pass learning model that was developed

12 Ladies and gentlemen can bring out the value of $\sqrt{ }$ 
cooperation between students

13 Overhead pass learning model developed can improve the $\sqrt{ }$ skill of passing volleyball

14 Ladies and gentlemen like the development of the overhead pass learning model

15 The overhead pass learning model developed is able to develop active student movements

The presentation of the value of one to one physical education teacher was obtained:

$12 / 15 \times 100=80 \%$

The next stage is testing small group products. The results obtained are as follows:

Table 6.Percentage of results of overhead pass model observations

\begin{tabular}{lccc}
\hline Value & $\begin{array}{c}\text { Number of } \\
\text { student }\end{array}$ & Category & Percentage \\
\hline $86-100$ & 1 & Very good & $8,33 \%$ \\
$71,00-85,99$ & 9 & Good & $75 \%$ \\
$56,00-70,99$ & 2 & Enough & $16,67 \%$ \\
$41,00-55,99$ & 0 & Less & $0 \%$ \\
$<40,99$ & 0 & Very less & $0 \%$ \\
\hline
\end{tabular}

The final next stage of development is large group product trials. The results obtained are as follows:

Table 7. Percentage of the results of the observation of the overhead pass model

\begin{tabular}{lccc}
\hline Value & $\begin{array}{c}\text { Number of } \\
\text { student }\end{array}$ & Category & Percentage \\
\hline $86-100$ & 3 & Very good & $12,5 \%$ \\
$71,00-85,99$ & 21 & Good & $87,5 \%$ \\
\hline
\end{tabular}




\begin{tabular}{llcl}
\hline $56,00-70,99$ & 0 & Enough & $0 \%$ \\
$41,00-55,99$ & 0 & Less & $0 \%$ \\
$<40,99$ & 0 & Very less & $0 \%$
\end{tabular}

\section{DISCUSSION}

The development of the upper passing learning model uses the research and development method with the ADDIE intructional design. ADDIE stands for Analyze, Design, Development, Implementation and Evaluation (Aldoobie, 2015; Branch, 2010; Drljača \& Latinović, 2010; Hishamudin, 2016; Hsu, Lee-Hsieh, Turton, \& Cheng, 2014; Kurt, 2017). The research begins with conducting a needs analysis by identifying problems in accordance with problems in the skills or knowledge fields of students (Cheung, 2016), In addition, the ADDIE analysis phase begins with a teaching problem that produces a careful view of the student population and student characteristics (Hess \& Greer, 2016).

The volleyball development model is based on previous research, namely the development in the development of lower-fitting instruments in volleyball games (Daulay \& Daulay, 2018; Pranopik, 2017) previous research, namely developing smash techniques in volleyball games with research and development research and development (R\&D) methods. This research begins with a needs analysis by making observations, the results of the observations show that in the learning process of volleyball, especially the material fitting for the problems faced, namely the difficulty of students doing top pasing, students when participating in learning activities of pasing over volleyball games students seem to have difficulties. do these movements, so that the desire of students to pass over is reduced, this causes students to be less able to do top passes properly. In volleyball, the overhead pass is an important skill for passing a ball and making a set to attackers. In the present study, we analysed the overhead pass motion and involved muscle activity with special attention to the stretch-shortening cycle (SSC), Overhead pass is characterised by the movement in which the wrist is first dorsiflexed with a dropping ball and then flexed to push the ball (Ozawa, Uchiyama, Ogawara, Kanosue, \& Yamada, 2019), and this occurs because the 
elastic energy stored in the muscle and tendon during the eccentric contraction can be utilised (Padulo et al., 2013). Currently, how to teach upper pass skills is not necessarily evidence-based because the upper pass movement has not been analyzed, although the order of other movements in volleyball such as attacking, jumping and blocking is clear. (Ficklin, Lund, \& Schipper, 2014; V., T., G., M., \& E., 2010). Problems occur because things such as the lack of variation in teacher teaching techniques, teaching material sources and learning media are said to be very few, then literacy analysis where there is still a lack of learning techniques to teach top service, then the corner teacher needs analysis really requires recorded teaching steps so that can teach top serve technique well.

The second stage in this research is product design starting from designing goals to be achieved in the learning process, and formulating goals to be achieved besides that the design / design phase helps to focus and improve the researcher's efforts and create designs where they can then build teaching content. an interesting and learning experience (Hess \& Greer, 2016). The goals in this case lead to the development of courage, independence, and motor development of children in the field, including; planning the preparation of learning technique materials for learning, planning the use of effective language, planning procedures for implementing top-level techniques, planning for experts in their fields, and planning the learning process or daily activity plans so as to examine instructional goals, these instructional objectives are obtained based on the learning implementation plan so that it is in accordance with the learning provided by sports and health physical education teachers. This study presents 3 experts in validating the development model of learning pasing over volleyball, namely; physical education, sports and health specialist, and volleyball expert and linguist. The results of the research on this design resistance showed that the learning model for this learning process obtained a percentage of $87.5 \%$ of Physical education experts, $90 \%$ of volleyball game experts, and $87.5 \%$ of linguists from expert validation results showed that the learning model was fitting for the game. volleyball Valid or worth using. 
The next stage is the development stage, which is an activity consisting of one-on-one trials and small group trials of products that have been declared valid. The one-on-one test was carried out on 1 physical education teacher as a user, namely by providing a questionnaire on the top learning technique developed and the average percentage result was $80 \%$ for the development of the top learning model where these results were included in the "feasible" (valid) category where The teacher feels that they can use the learning model well, then there is a small group trial where 12 students of class VIII junior high school are tested with the results of 1 student (8.33\%) in the very good category, 9 students (75\%) are in the good category, and 2 students (16.67\%) are in the sufficient category. Based on these results it can be seen that students have skills that are in the good category after using this product. After small-scale trials, revisions were made based on input from the teacher and observations of students during the implementation of the upper-pass learning model in the field. The end of this research is at the stage of a large-scale trial using 24 students as respondents. The large group trials in this study were intended to review the product of the development of the pasing learning model of volleyball in class VIII students of junior high school no 1 Palembang, by measuring the achievement of product development goals by measuring what the development goals had been able to achieve, namely improving results. learning pasing over the volleyball game, besides this group try-out is used as feedback to make it easier for teachers to plan quality, effective, and efficient learning.

This research resulted in the development of a valid passing-over learning model that can be used for learning passing on junior high school students from previous research (Destriana, Destriani, Yusfi, \& Muslimin, 2020) stated that the development of the fitting model can improve junior high school student learning outcomes (Huang, 2019) produce a volleyball leg movement teaching model based on a combination of the frontal double hand overhead pass technical action model can improve the upper pass results, then the research results (Barsingerhorn, Zaal, De Poel, \& Pepping, 2015) resulting that in order to develop fitting and decision-making skills, it is necessary to be encouraged to practice 
different techniques simultaneously in situations where the same technique is given, rather than train different fitting techniques separately, further research results (Destriana, Destriani, \& Yusfi, 2018), regarding the development of underpassing learning that can improve the results of passing learning, besides that (Destriani, Destriana, Switri, \& Yusfi, 2019), Based on the results of his research that the development of mixed volleyball can improve the learning outcomes of volleyball from these studies, it can be concluded that the development of the upper pass learning model can be done in various ways, thus this research produces overhead pass learning model that is valid or suitable for use for overhead pass learning of volleyball especially at the junior high school level.

\section{CONCLUSION}

The conclusion of this research is that the development product in the form of a learning model for volleyball is valid or suitable for use in the volleyball learning process in class VIII of Junior High School. It is hoped that the findings of this study can be an additional reference in learning upper pasing in volleyball so that it can improve the results of passing skills over games in volleyball games.

\section{ACKNOWLEDGEMENT}

Thank you to all those who have supported the implementation of market development research for this volleyball game. Especially the Chancellor of Sriwijaya University for providing research assistance to the Science and Technology Grant, in addition to all research members and the school, namely the Palembang 1 Public Junior High School, from the principal, Physical Education teachers, as well as students and female students.

\section{REFERENCE}

Aldoobie, N. (2015). ADDIE Model Analysis phase. American International Journal of Contemporary Research.

Barsingerhorn, A. D., Zaal, F. T. J. M., De Poel, H. J., \& Pepping, G. J. (2015). Shaping decisions in volleyball an ecological approach to decision-making in volleyball passing. International Journal of Sport Psychology. 
https://doi.org/10.7352/IJSP.2013.44.197

Branch, R. M. (2010). Instructional design: The ADDIE approach. In Instructional Design: The ADDIE Approach. https://doi.org/10.1007/978-0387-09506-6

Cheung, L. (2016). Using the ADDIE Model of Instructional Design to Teach Chest Radiograph Interpretation. Journal of Biomedical Education. https://doi.org/10.1155/2016/9502572

Daryono, D., \& Almy, M. A. (2021). Peningkatan Keterampilan Bermain Bola Voli Mahasiswa Melalui Latihan Gaya Self Check. Halaman Olahraga Nusantara Ilmu Keolahragaan). https://doi.org/10.31851/hon.v4i1.5101

Daulay, B., \& Daulay, S. S. (2018). Pengembangan Variasi Latihan Kombinasi Passing dan Smash dalam Bola Voli. Jurnal Pendidikan Teknologi Dan Kejuruan. https://doi.org/10.24114/jptk.v20i1.11040

Destriana, D. (2019). LATIHAN PASING ATAS DOUBLE CONTACT TERHADAP KETERAMPILAN BOLA VOLI. Altius: Jurnal Ilmu Olahraga Dan Kesehatan. https://doi.org/10.36706/altius.v7i1.8112

Destriana, D., Destriani, D., \& Yusfi, H. (2018). Pengembangan Teknik Pembelajaran Pasing Bawah Permainan Bola Voli Smp Kelas Vii. Sebatik. https://doi.org/10.46984/sebatik.v22i2.324

Destriana, Destriani, Yusfi, H., \& Muslimin. (2020). The Implementation of Underpass Learning Techniques Volleyball for Junior High School. https://doi.org/10.2991/assehr.k.200323.098

Destriani, D., Destriana, D., Switri, E., \& Yusfi, H. (2019). The development of volleyball games learning for students. Jurnal SPORTIF : Jurnal Penelitian Pembelajaran.https://doi.org/10.29407/js_unpgri.v5i1.12605

Drljača, D. P., \& Latinović, B. (2010). ADDIE model. Zbornik Radova ITeO2010.

Ficklin, T., Lund, R., \& Schipper, M. (2014). A comparison of jump height, takeoff velocities, and blocking coverage in the swing and traditional volleyball blocking techniques. Journal of Sports Science and Medicine.

Hess, A. K. N., \& Greer, K. (2016). Designing for engagement: Using the ADDIE model to integrate high-impact practices into an online information literacy course. Communications in Information Literacy. https://doi.org/10.15760/comminfolit.2016.10.2.27

Hishamudin, F. (2016). Model ADDIE. Universiti Teknologi Malaysia.

Hidayat, A., Muslimin, M., \& Kasim, A. (2018). Pengembangan perangkat tes dan pengukuran passing bola voli berbasis komputer. https://doi.org/10.5614/sostek.itbj.2018.17.2.11

Hsu, T. C., Lee-Hsieh, J., Turton, M. A., \& Cheng, S. F. (2014). Using the ADDIE model to develop online continuing education courses on caring for 
nurses in Taiwan. Journal of Continuing Education in Nursing. https://doi.org/10.3928/00220124-20140219-04

Huang, X. (2019). Volleyball footwork movement teaching mode based on the fusion of frontal double handed overhead pass technical action model. Proceedings - 2019 11th International Conference on Measuring Technology and Mechatronics Automation, ICMTMA 2019. https://doi.org/10.1109/ICMTMA.2019.00164

Ikeda, Y., Sasaki, Y., \& Hamano, R. (2018). Factors influencing spike jump height in female college volleyball players. Journal of Strength and Conditioning Research. https://doi.org/10.1519/JSC.0000000000002191

KEMAMPUAN GURU TENTANG PENDIDIKAN JASMANI DAN PENILAIAN BERBASIS KINERJA. (2013). Cakrawala Pendidikan. https://doi.org/10.21831/cp.v0i2.1481

Kurt, S. (2017). ADDIE Model: Instructional Design. https://doi.org/10.1017/CBO9781107415324.004

Marsiyem, M., Destriana, D., \& Pratama, R. R. (2018). PENGEMBANGAN MODEL PEMBELAJARAN SERVIS BAWAH PERMAINAN BOLA VOLI. Sebatik. https://doi.org/10.46984/sebatik.v22i2.323

Ozawa, Y., Uchiyama, S., Ogawara, K., Kanosue, K., \& Yamada, H. (2019). Biomechanical analysis of volleyball overhead pass. Sports Biomechanics. https://doi.org/10.1080/14763141.2019.1609072

Padulo, J., Tiloca, A., Powell, D., Granatelli, G., Bianco, A., \& Paoli, A. (2013). EMG amplitude of the biceps femoris during jumping compared to landing movements. SpringerPlus. https://doi.org/10.1186/2193-1801-2-520

Pane, A., \& Darwis Dasopang, M. (2017). BELAJAR DAN PEMBELAJARAN. FITRAH:Jurnal Kajian Ilmu-Ilmu Keislaman. https://doi.org/10.24952/fitrah.v3i2.945

Pranopik, M. R. (2017). PENGEMBANGAN VARIASI LATIHAN SMASH BOLA VOLI. JURNAL PRESTASI. https://doi.org/10.24114/jp.v1i1.6495

Pratiwi, E., \& Anggara, N. (2021). Pengembangan Model Passing Bawah Bola Voli Pada Atlet Pemula Mahasiswa Universitas Islam Kalimantan MAB Kalimantan Selatan. Halaman Olahraga Nusantara (Jurnal Ilmu Keolahragaan). https://doi.org/10.31851/hon.v4i1.5106

Rohendi, A. (2020). Pengembangan Model Pembelajaran Passing Atas Bola Voli Berbasis Permainan. JPOE. https://doi.org/10.37742/jpoe.v1i1.2

V., H., T., S., G., M., M., V., \& E., D. (2010). The isokinetic strength profile of quadriceps and hamstrings in elite volleyball players. Isokinetics and Exercise Science. 